\title{
PERFORMANCE MEASUREMENT PRACTICES OF PUBLIC SECTORS IN MALAYSIA
}

\author{
Jusoh RUZITA \\ Rudyanto AZHAR \\ Haslida ABU HASAN \\ Faculty of Business\&Accountancy, University of Malaya
}

\begin{abstract}
This paper focuses on the adoption of performance measurement in public sectors in Malaysia. The objectives of the study are to examine the extent to which performance measurement is designed and linked to the strategy and the extent of performance measures being used in a balanced manner in accordance to the balanced scorecard (BSC) approach. A survey was conducted to senior civil servants and the results reveal that the design of public sector performance measurement system is moderately well developed. In examining the balanced nature of performance measurement, this study reveals that there is an overall lack of balanced indicators except for indicators on financial and nonfinancial such as input, activity and output indicators.
\end{abstract}

Key words: performance measurement, balanced scorecard, public sector

\section{INTRODUCTION}

There is an increasing interest on the performance measurement in government since late 1980s encouraged by the new public management movement (Osbourne and Gaebler, 1992). Many governments have adopted some sort of performance measurement initiatives to enhance their services and promote transparent and accountable government. However, implementations and practice of performance measurement has been recognized as much less than comprehensive (Niven, 2002). Although much has been written in theory about performance measurements, less is known in practice about their operation, especially in the public sector and in Malaysian context. Therefore this paper reports an attempt to investigate the perception of senior civil servants of Malaysian public sector on the performance measurement design and implementation. A study was conducted to examine the extent to which performance measurement is designed in line with the strategy, how it has been implemented and the extent to which it has been used. This study resembles partly the research done by Hoque and Adams (2008) in the Australian government. There were several reasons for undertaking this study. The first reason is to date, the design and choice of the performance management systems within government departments received minimum attention from researchers and least explored especially in Malaysia. The most recent study was conducted by Hoque and Adams (2008) in Australia and similar study was also done much earlier on state and local governments by the Government Accounting Standards Board and National Academy of Public Administration in the USA in 1997. Both studies looked into the performance measurement practices in the public sectors. This study extended earlier investigation by other researchers mentioned earlier and adopts a survey approach using questionnaires developed partly based on Hoque and Adams (2008). Recent studies in regard to performance measurement in Malaysia were done on the private sector by Othman et al. (2004) focusing on the limitations faced by a Malaysian telecommunication company in implementing balanced scorecard (BSC) and Jusoh et al. (2006, 2008a, 2008b) on performance measurements and balanced scorecard usage in Malaysian manufacturing firms. It is hoped that this short exploratory study will promote researchers' interest to investigate further into the issues of adapting and sustaining performance in the Malaysian public sector. The second motivation for conducting this study is due to increasing efforts taken by the Government of Malaysia in adopting outcome-based performance monitoring and evaluation method on the governments' projects and programs. These efforts emphasizes on outcome/impact instead of processes. In line with this new development, the Malaysian government has also introduced the use of key performance indicators (KPIs) to all ministers which has resulted in the creation of a new unit called 'Unity and Performance Unit' under the Prime Minister's Department. It is therefore timely to examine if the BSC or its distinguishing characteristics can be used as an effective performance measurement and management tool for the government sector 
especially its application in the government of Malaysia. Hence, focusing on the Malaysian public sectors, this paper attempts to answer the following questions related to the design, implementation, uses, and benefits as well as shortcomings of performance measurement system:

1. How is the performance measurement being designed?

2. How is the performance measurement being implemented and used?

3. What are the benefits and important aspects of successful implementation of performance measurement system?

\section{LITERATURE REVIEW}

\section{Evolution of Performance Measurement}

The concept of performance management has been going through a gradual change over the years. Performance measurement is defined as management and control systems that produce information to be shared with internal and external users (Henri, 2004). Furthermore, as it encompasses all aspects of the business management cycle, performance measurement constitutes a process for developing and deploying performance direction (Nanni et al., 1992). Neely et al. (1995) view performance measurement as the process of quantifying the efficiency and effectiveness of action while the performance measure represents the metric used to quantify the efficiency and/or effectiveness of this action. Performance measurement based on traditional cost or management accounting system that was introduced in early 1900s is more for fulfilling the requirement of external reporting and government (Johnson \& Kaplan, 1987). Johnson and Kaplan (1987) argued that traditional performance measurement systems focus too heavily on the accounting or financial based measures and tend to ignore the non-financial measures. In other words, no or less emphasis is given on longterm value creation, particularly for the intangible and intellectual assets, that generate future growth to the organization. This is because these intangible assets could not be easily quantified in terms of financial or monetary values. Managing organization's intangible assets such as customer relationships, innovative products and services, high-quality and responsive operating processes, and employee capabilities and skills can only be done through the use of non-financial measures. Accordingly, during the last two decades, an increasing number of companies have implemented performance management systems (PMS) that are based on critical success factors (CSF) and key performance indicators (KPI). Organisations, especially those in the private sector, have implemented a number of broader performance measurement and management system (PMS) tools such as Activity-Based Costing/Management (ABC/M), Benchmarking, Total Quality Management (TQM), Business Process Reengineering (BPR) and arguably the so-called best tool, the Balanced Scorecard (BSC). In a recent survey, Rigby (2003) reported that the BSC is one of the key "compass setting" tools used by managers. Lingle and Schiemann (1996) describe the results of a study that confirms that companies who balance financial and non-financial measurements, but also link strategic measures to operational ones, update their strategic scorecard regularly and clearly communicate measures and progress to all employees, are better performers. Surveys among corporate executives conducted by the consulting firm Bain and Company revealed that by 2004, 64 percent of their respondents in North America and 57 percent of the respondents worldwide were using BSCs in their companies (Rigby and Bilodeau, 2005). Increasingly, managers have found value in monitoring indicators other than the financial measures. A recent survey of senior executives reveals that shortterm financial measures rank fifth behind four non-financial measures in terms of perceived importance (Ittner and Larcker 2001). Atkinson et al. (1997, 25) also conclude that "performance measurement systems based primarily on financial performance measures lack the focus and robustness needed for internal management and control". This is because the information developed using traditional performance measurement framework for external users is inadequate and insufficient for internal users. The perceived restrictions of traditional accounting-based measures are numerous of which Ittner and Larcker (1998a) listed eight most common limitations, namely, too historical and "backward-looking", lack of timely signals, lack of predictive ability to explain future performance, reward short-term or incorrect behaviour, lack of actionability, too aggregated and summarized to guide managerial action, reflect functions instead of cross-functional processes, and give inadequate guidance to evaluate intangible assets. Traditional financial ratios have worked as important tools of measuring organisational performance in the past. Kaplan and Norton $(1992,71)$ suggest that they "worked well for the industrial era, but they are out of step with the skills and competencies companies are trying to master today". Their relevance in the information age where the 
market has no boundary and organisations are competing for talents is questionable. The situation may worsen when the firm is compelled to pursue short-term goals at the cost of the organisation's long term objectives (Anand, Sahay, \& Saha, 2005). Eccles, (1991) felt that the leading indicators of business performance cannot be found in the financial data alone.

\section{Performance Measurement in Public Sector Organisations}

'New public management' discussion surrounds only one key word, which is 'performance' (OECD, 1993: p.7). Performance has been the agenda for new way of doing business in the public sector and that involves paradigm shift towards entrepreneurial government (Osbourne and Gaebler, 1993). Thus, public sector nowadays needs to be managed like their business counterpart. However, the design of performance indicators in both private and public sectors are very difficult to match because performance is a broad concept which has various meanings for different audience in a different context (Carter, 1991). Nevertheless, managers of public sector have to face a number of performance measurement-related challenges resulting from the new public management initiative. Public agencies are becoming more aware of their necessity to develop and implement practices and procedures that will make them more business-like (Dixon, Kouzmin and Korac-Kakabadse, 1998). Governments around the world are under pressure to control their costs and improve their services -they are expected to be responsive and accountable not only to their departmental secretary, minister and parliament but also to client groups in the marketplace, even when their respective interests are in conflict (Dixon, Kouzmin and Korac-Kakabadse, 1996). US Comptroller General David M. Walker, in testimony to a US Senate subcommittee on how to improve the federal government's approach to managing its people, noted that the landmark federal management reforms of the 1990s signaled the arrival of a new era of accountability for results (Walker, 2000). The US federal government will have to go beyond a zero tolerance for waste, fraud and abuse and create a government that is better equipped to deliver efficiently, economically and effectively on its promises to the US people. Randor and Lovell (2003) believe that there is a need to reinforce accountability, so that they are clearly held accountable for the resources they use and the outcomes they achieve. In response, government administrators have begun introducing changes and implementing modern private sector management tools in their organisations to deal with the financial constraints and increasing demand in terms of accountability to stakeholders (Ho \& Chan, 2002). According to the World Bank's Independent Evaluation Group's report, growing number of governments are working to improve their performance by creating systems to measure and help them understand their performance (Mackay, 2007). These monitoring and evaluation (M\&E) systems are used to measure the quantity and quality of the goods and services (i.e. the outputs) that the state provides and to measure the outcomes and impacts resulting from these outputs. The M\&E systems are also a medium to facilitate understanding of the causes of good and poor performance. The report highlights the various whole-of-government M\&E initiatives around the world (some which are named differently) such as in the Australia, Chile, Colombia, United States (Program Assessment Rating Tool, PART), the United Kingdom (Public Sector Agreement), South Africa, Uganda (National Integrated M\&E System) etc. Niven (2002) among others has been actively working with a number of local authorities in balanced scorecard implementation such as the City of Charlotte and Transport Department of Michigan, USA. In European countries such as the United Kingdom, Finland, the Netherlands and Sweden, performance measurement has been implemented rather pervasively as reported by Pollit (2005). Pollit emphasizes that the UK's public sector has had the strongest history on performance measurement and that performance measurement has become almost universal in the northwestern European governments and it goes well beyond rhetoric and into practice.

However, there are underlying differences between the private sector and the government sector. Private sector and government sector organisations organize functions differently, because their budgeting processes, regulatory and accountability regimes are different (Dixon, Kouzmin and KoracKakabadse, 1998). Consequently, priority objective would have been different too as the "financial" perspective (which is understandably the most important aspect of a profit oriented organisation) cannot be a bottom-line objective for government organisations, but rather may provide a constraint by limiting spending to budgeted amounts (Kaplan \& Norton 1996: pp.179-80). Two important features of the public sector are:

i) bureaucrats often serve several masters which include services' users, services' payers, politicians and professional organizations;

ii) the consequence of serving different masters resulting in the bureaucrats often have several 
ends to achieve, i.e. they are often expected to increase both efficiency and equity when delivering services to the public (Dixon, 2002).

Steven Van de Walle (2007) highlights that the main problem of measuring public sector performance lying on a conceptual instead of measurement. It is a conceptual problem because in order to measure government and government performance, you first have to define government and agree on its objectives. Failure to define those areas would render the measuring effort as technically correct, but at the same time meaningless. Objectives, as in most cases of governments in the world, may not be revealed - objectives may be contradictory, or policy makers may just not know what exactly their objectives are. When conflicting and/or vague objectives is an essential feature of governing, measuring government performance will be merely a political exercise at best.

Public sector also apply balance score card (BSC) as their control mechanism. A scorecard can be considered "balanced" if it contains financial and non-financial measures, driver and outcome measures, tangible and intangible measure and internal and external constituents. Niven (2003) describes a BSC as a carefully selected set of quantifiable measures derived from an organisation's strategy. Strategy is an integral element of a BSC framework which suggests that the foundation of measuring organisational performance should be derived from its vision and strategy. Therefore, any measurements chosen within the four perspectives (financial, customer, internal processes, and learning and growth) should be able to explain the level or extent of achievement of the strategy. In linking strategy to balanced scorecard, it is important to translate strategy into measurable achievement so that it can help to guide the organisation in explaining those typically mouthful words into simple and achievable adverbs and nouns (Kaplan and Norton, 1996). Hence, this study attempts to explore the extent to which performance measurement in the public sector is being developed based on their strategy. Despite some underlying differences between the private and the government sector, government organisations are increasingly recognizing the BSC as an important performance measurement and management tool. They are also looking for appropriate performance measurement systems to ensure employees are rewarded for good performance. Effective performance management requires fact-based decision making and one of the first requirements is relevant and reliable data. With multiple perspectives (one of the important elements of the current version of the BSC) data at hand, government agencies can show the outcomes and effects of their efforts as real as possible, and taxpayers can judge the agencies' accomplishments across a range of measures and decide whether they are getting the best possible service value for their tax dollars. Apparently, there has been very little research done on how a standard BSC (originally developed for the private sector), can be effectively applied in the public sector. The effective use of the BSC in the public sector as a performance measurement and management tool represents a gap in the literature (Chan, 2002). Major concern would be on the potential adjustment to the BSC should it be adopted in a public sector. Potential adjustment to the structure of the BSC and the use of composite measures in evaluating an organization is worth to be discussed further. There are some obvious weaknesses of the current version of the BSC when it is applied in the government sector especially with regard to its design and structure. The differing objectives of the government sector indicate some problems of the application of the current version of the BSC in government organisations. Government organisations often place their customers or constituents (not the financials) at the top of their strategy maps (Kaplan \& Norton 1995, p.79). But the current version of the BSC fails to provide a blueprint as to how other perspectives (learning and growth, internal business process and financial) may ultimately influence and affect customers. A clear distinction between the private and the public sector is that in the private sector, it is the customer who pays for the service and receives the service (Kaplan \& Norton 2001, p.134). In the public sector, however, the customers or citizens do not necessarily pay for the service they receive (or perhaps pay only proportionately). In other words, the citizens do not receive service in direct proportion to their tax payments and any form of fiscal contribution. Therefore, unlike the private sector, the "financial" perspective is not the bottom-line objective for government organisations (Kaplan \& Norton 1996, pp.179-80), but customer perspective is. Hence, in a causal relationship manner, it is very important that a BSC translates all relationships into customer satisfaction but not necessarily into financial success. In fact, in the government sector, it is most often that financial success leads to customer satisfaction (as contrasted with the private sector, where customer satisfaction usually leads to increased revenue). 


\section{RESEARCH METHODS}

\section{Instruments, sample and survey procedure}

The questionnaires were formulated after a lengthy review of the literature in performance measurement and balanced scorecard. A total of 35 questions derived selectively from various previous researches such as Hoque and Adams (2008), Kald and Nilsson (1999), and Marr (2005). The questionnaire is broadly divided into three sections, namely: Strategy, Performance Measurement, and Respondent's Background. Strategy section gives the respondents an opportunity to present his/her understanding of his/her unit's strategy and its possible relationship with performance measurement system. Performance measurement section deals with questions related to the design, implementation, and use of the PMS in his/her organisation, sector or division. Majority of the questions were being rated on a 5-point Likert Scale where 1= "To a little or no extent", $2=$ "To some extent", $3=$ "To a moderate extent", $4=$ "To a large extent" and 5= "To a very large extent". There are more than 900 federal and state government agencies throughout Malaysia and approximately 77 ministries and federal government agencies having headquarters in Putrajaya. This study was limited to the government agencies having their head offices at Putrajaya in view of the vast locations and respondents which may include many groups and sub-groupings. This would be more practical and achievable given the time and resource constraints of the study. Furthermore, the questionnaire designed demands responses from the senior executives and most senior executives normally are positioned at the head offices in Putrajaya. Concurrent with time constraint and position of the participants, the questionnaires were administered personally to respondents' offices in Putrajaya. All respondents were assured that their responses will be treated confidential; the cover letter states that 'only aggregates will be used for the research and that no individual organisation will be linked to specific responses'. The cover letter also states that filling up of personal information at the end of the questionnaire is optional. Out of 73 questionnaires sent out, only 51 were returned (70 percent), seven via fax and the rest were personally collected. Majority of responses were obtained from the divisional level (38 respondents, 74.5 percent), followed by sectoral (12 respondents, 23.5 percent) and organisational level ( 1 respondent, 2 percent). The respondents came from three management levelsSenior Management, Middle Management, and Lower management level, code as others. There are 28 males respondents as compared to 20 females, while 3 respondents' data were missing. Forty seven respondents (92.2 percent) have been in the government service for 12 years and above and among them, 24 (47.1 percent) respondents have been with the same unit between 2 to 4 years. Twenty four of the respondents ( 47.1 percent) have a university degree while 21 of them graduated with a master's degree.

\section{RESULTS AND DISCUSSION}

Survey data of this study was analyzed using descriptive statistics to answer the three research questions posed earlier. As the study was an exploratory in nature, analysis using descriptive statistics deems to be sufficient in order to give a general idea about the current state of nature of performance measurement systems practiced in the Malaysian public sector. Therefore, results are presented according to the three research questions.

\section{How is the Performance Measurement Being Designed?}

Before the respondents were asked on the specific questions relating to the design of performance measurement, two questions were asked regarding the business performance measurement (BPM) approaches. Out of 44 responded (7 were missing), 41 of them (93.2 percent) said that they had heard and are aware of the balanced scorecard (BSC) approach. In another question asking them whether their performance measurement system is a balanced scorecard, only 7 out of 51 who responded (13.7 percent) say that their performance measurement system is to a large and very large extent resembles a BSC whilst 27 respondents (52.9 percent) reply that their performance measurement systems least likely to resemble a BSC. Among 51 who responded, only five respondents' organisations (9.8 percent) have actually implemented BSC whilst 28 organisations (54.9 percent) are still in the consideration stage, while 12 have rejected the idea and six have not considered it at all. Government's officials in Malaysia are provided with 'manual of office procedures' and corresponding 'desk file' in an effort to increase efficiency. Both manual and desk-file clarify the functions of organization, the duties of individuals within it and also facilitate learning and continuity. These are resemblance of balance-scorecard to some extent. However, the extant of it 
balancing/coordinating between functions as well as its usefulness is another interesting issues which will be explored in the following questions.

This study also attempts to find out if the unit is using any other performance measurement approaches than the balanced scorecard. This is because in Marr's (2005) study, out of 276 respondents, 167 (61.0 percent) are using BSC together with other quality-based approaches such as total quality management, Baldrige, Six Sigma and economic value added (EVA). The results of this study (see Table 2) show that 32 organizations (62.7 percent) have implemented ISO and some sort of a customized KPI system. Eight organizations (15.7 percent) have implemented activity based costing and only 3 (5.9 percent) have implemented six sigma. What is interesting to note is that there is one respondent from each of those who had implemented ISO, Six Sigma and activity based costing had eventually abandoned the approach. Cross tab analysis resulted in 43.1 and 39.2 percent of those who have implemented ISO and customized KPI system respectively are also considering implementing BSC. Many public sector organizations in Malaysia are seriously applying and working towards accreditation, in particular the ISO. Thus, it is not a surprise for these organizations wanting to achieve clearer function-specification, coordination of tasks and faster responses through adopting business-like management style. Pressure from criticism by the public also contributes towards this trend. A 'open-office' concepts been applied in the effort to facilitates communication and close supervision as well as creating business-like atmosphere in government departments. A move towards outcome-based performance measurement and increasing awareness towards employing a balanced set of KPIs exhibit that there is a high probability that the public sectors will increasingly adopt the BSC approach.

In view of having strong effort and emphasize on measuring performance, respondents were asked on the specific questions concerning the design of performance measurement system, questions relating to the extent of performance measures being derived from the organisational strategy and the extent to which performance measures are used in a balanced manner in accordance to the BSC approach. Results show that 51 percent of respondents declare that their unit's strategy is officially documented. Having an official documentation on strategy is a good sign for concern over its outcome. Another good indicator is that 62.7 percent of respondents feel that their operational strategy is to a large and very large extent influenced by the organisational strategy, which suggests the good practice of reflecting organizational strategy in operational strategy to some extent. The overall mean for performance measurement deriving from strategy is 3.31 , hence, it can be deduced that the performance measurement of Malaysian public sectors is to a moderate extent being developed based on organisational strategy. The result, although in right direction, is far from the findings by Kald and Nilsson (1999) on 800 business units in the Nordic countries where there is a relatively strong connection between strategic plan and the measures used. This could due to the difficulties in translating the strategy into operational and measureable terms within a public sector as strategy is often nebulous and visionary as Kaplan (1996) suggests that strategy can be a foreign concept to a public sector organisation. Flynn (1993) wrote that politicians often place a high value on ambiguity and vagueness because their measurement should be held on what they are accountable for. Questions were also asked in terms of dimension of performance indicators, ten dimensions were suggested (output, cost \& processes efficiency \& quality measures, activity/process, customer satisfaction, outcomes, financial, inputs, learning and growth, Socially and environmentally related measures and innovation. Results indicate that all the ten performance measurement dimensions are used only to some extent by the Malaysian public sectors (mean scores are below 3.0). However, among the 10 dimensions, activity/process measures are used most extensively (mean= 2.49), followed by output measures $($ mean $=2.29)$, financial measures $($ mean $=2.25)$, inputs measures $($ mean $=2.25)$, and customer satisfaction measures (mean $=2.24$ ). Majority of the respondents reported that they use activity/process measures (60.8 percent) and output measures (58.8 percent) to a large and very large extent. The findings on output and activity/process measures are quite similar to the findings reported by Hoque and Adams (2008) in the Australian government. As expected, socially and environmentally related measures $($ mean $=1.47$ ) and innovation related measures are used least by the Malaysian public sectors. The former is reported to have been used to a little or no extent by 60.8 percent of respondents and the latter by 58.8 percent. The mean score for all 10 dimensions is 2.94 , and therefore, it can be concluded that Malaysian public sectors use balanced performance measures only to some extent. It seems that the measurements are to some extent being balanced between financial and non-financial indicators because the financial measurements are being used to some extent $($ mean $=2.25)$, while other non-financial performance measurement dimensions such as customer satisfaction and process efficiency and quality are being used to some extent too. 
Government of Malaysia issued a manual called 'guidelines for establishing performance indicators in government agencies' in 1993 to guide agencies in implementing performance measures. The performance indicators were incorporated into annual budget estimates, annual reports and other feedback to the government. Thus, it is not a surprise that from the mean scores, the results also indicate that there seems to be a somewhat balanced set of performance measurements between input and output indicators as both types of measurements are being used to large and very large extent by 45.1 percent and 58.8 percent of respondents, respectively. This could be due to the current Malaysian government initiative of implementing Annual Work Target which was enhanced in 2002 (JPA, 2002) that requires every public servant to plan and document all core and non-core activities and deliverables to be accomplished for that particular year which include planned budgets, manpower, activities and trainings. However, with regard to input measures, this finding is quite different from Hoque and Adams's (2008) study whereby inputs and learning and growth measures were the least used in the Australian government. Not surprisingly, the least used performance measurement dimensions are socially and environmentally related measures (mean=1.47), measures on innovation ( mean $=1.53$ ) and outcomes measures (mean=1.69). An outcomes measure is defined as the measure that tracks the benefit received by stakeholders as a result of the organisation's operations (Niven, 2002). Outcome measure relates to the achievement of the organisation's overall goals such as reduced incidence of HIV, increased perception of public safety etc. The low percentage of usage of outcome measures among Malaysian public sector might not augur well with the aspiration of the Chief Secretary to the Government to institute outcome measurements in evaluating the achievement of the Ninth Malaysian Plan.

Another possible balanced set of indicators are between a driver and an outcome indicators. A driver indicator is a measure that leads to the achievement of outcome indicators and often includes the measurement of processes and activities (Niven, 2002). Since this study shows an extensive usage of inputs, activities as well as a moderate use of efficiency and quality measures as compared to outcome measures, therefore, we can fairly deduce that the public sector performance measurement system is seemingly lacking in terms of balanced driver-outcome indicators. The last aspect of a balanced set of measurements is from the perspective of internal vs. external stakeholders (Kaplan and Norton 1992; 1996). From our results, internal related measurements such as inputs, financial, activity/process, as well as output, are being used to a larger extent as opposed to external related measures. Except for customer satisfaction that were reported to have been used to a moderate extent ( 49.0 percent), other external related measures such as outcomes (47.1 percent) and social and environmental (60.8 percent) related measures have been used to little or no extent. Therefore, it seems that the Malaysian public sector has been measuring their achievement based most on internal yardstick instead of taking the cues from the stakeholders, customers or the public. To explore further on the use of socially and environmentally related measures, respondents were asked to rate on the extent of use of nine socially and environmentally related measures.

The mean score of overall nine social and environmental related measures is 2.28 suggesting that the social and environmental related measures are only being used to a little or no extent by the Malaysian public sectors. Among the nine measures, employee satisfaction measures received the highest mean score (2.06) with 74.5 percent of the respondents used these measure to a moderate extent. Interestingly, employee diversity measures received the lowest mean score with 1.18 and were used to little or no extent by 86.3 percent of the respondents. This is particularly interesting given the racial composition in the public sector has been a hot and sensitive issues debated recently (Ahmad, 2007; Abdullah, 2008). Ahmad and Abdullah wrote that according to the Public Services Commission's (PSC) statistic, only 1.78 percent of Chinese and 2.5 percent of Indian had applied to join the public sector in 2006 out of 486,802 total applicants. This goes to show how unpopular the work in public sector is to the non-Malays. According to Tan Sri Ismail Adam, the Director General of Public Service Department (PSD), his department and the PSC have been relentlessly doing their level best to eliminate the racial gap in the public sector (Ahmad, 2007; Abdullah, 2008). This survey however, shows that employee diversity is not one of their key indicators. Another interesting observation from the results shown in Table 6 is on the usage of natural resource conservation and emission level measure. A mean score of 1.39 suggests that they have little or no extent of use of the said measure. As alarming as it might suggest, the study by Hoque and Adams (2008) also reveals similar pattern. As part of government's efforts to preserve the environment, the new Prime Minister has taken the lead in restructuring the Ministry of Energy, Water and Communication into Ministry of Energy, Green Technology and Water effective 9 April 2009 (Prime Minister's Office, 2009). With the new name, perhaps there will be more attention and importance given to the natural conservation measures. 
Another social and environment related measure that is worth mentioning is the low attention given to the economic impact measures (mean $=1.55$ ). Being one of the key tenets in the New Economic Policy as well as in the Ninth Malaysia Plan, one would expect quite a number of ministries, departments and agencies would be addressing the eradication of hard core poverty, reducing overall poverty, tackling the socio-economic inequalities and bridging the income gap between rural and urban area as well as among races.

\section{How is the Performance Measurement Being Implemented and Used?}

Several questions relating to performance measurement implementation and use were asked. The following sub-sections discuss the management/employee participation and communication channels involve in performance measurement system implementation as well as recording, updating and analysis of performance data involved.

\section{Participation and Communication Channels}

In regard to participation in the implementation process, the senior management team comprising those in the corporate planning, services \& operations as well as the policy groups are to a large and very large extent involved in development of performance measurement (mean $=3.59)$. The results on participation suggest the robustness of input and activities in regard to performance measurement, which is positive for the reliability and validity of the performance instruments they developed. Abu Hasan (2009) in her study of English local government performance measurement observes that participation in the development and assessment processes facilitates performance improvement within organizations. Having a consultation between various parties in the development process does promote trust towards the performance instruments and encourage members of the organization to achieve what they together have provided input. Therefore, ensuring balanced participation could promise better measurement instruments and performance. In terms of communication channels, this study found 62.7 percent of the respondents have reported use of information sessions (mean, 3.86) and $60.8 \%$ have used memo (mean $=3.69$ ) as their major communication channels to a large and very large extent. Having indicators and measured performance will be ineffective if there is no communication. In a similar study, Abu Hasan (2009) documented that efficient use of electronic medium of communication such as emails and websites works wonders for performance measurement initiatives, websites can be utilized as medium of information dissemination where the organization who measure performance would provide all the details on what criteria they look at, how to go about the criteria as well as results and feedback of their evaluation. Organizations measured also use websites to publish various achievements and work that they have done. Trust could also be improved if the organization exhibit greater transparency by providing more information about initiatives and achievement through their websites. Thus, using memos and information session is not as effective as using emails and websites as communication channels.

\section{Recording, Updating, and Collecting Performance Data}

The survey also asked the respondents to indicate the extent of use of methods or system to track, record, and collect data for performance measurement. Results indicate that spreadsheet application is being used to a large and very large extent (47.1 percent; mean, 3.18) as compared to ERP and specialized packaged PMS which are the being used to a little or no extent. The dominant method of data collection is found to be through manual basis where 51.0 percent (mean $=3.33$ ) have used it to a large and very large extent such as via hardcopy or email submission of spreadsheet and words document. This could be due to lack of resources in terms of budget to acquire systems or training to enhanced workforce ability to deal with technology. Thus, they resort to manual documentation which would be the simplest but could prove tedious and difficult to share and coordinate. The highly use of spreadsheet applications and manual data collection indicates that the level of use of IT and information system sophistication (ISS) is still low among many Malaysian public agencies. Classe (1999), for example, noted that simple spreadsheet tools might be sufficient at the initial stage of implementing PMS, but to make the method an integral part of the strategic performance measurement and management, automation will usually be necessary. Bernard Marr (2005) reports in his study that even though 45 percent of respondents use spreadsheet applications, such as Microsoft Excel, as the prime tool for the business performance measurement and management (BPM) activities, the users are not satisfied with their spreadsheet applications as 18 percent felt that they worked 
poorly as tools to measure and manage performance. The lack of suitable IT platform could be due to the cost of acquiring ERP that might run into millions of ringgit as according to Spathis and Constantinides (2003), the cost is not correlated to the sum of benefits of its implementation. This finding aggravates the concern stated earlier about the issue of changing or rotating the staff assigned to collecting, analysing and reporting performance measurement. Without a standard process supported by an established IT platform and dedicated staff, there could be a further challenge in monitoring and evaluating governance that could go undetected and might jeopardize the whole integrity and sustainability of the PMS initiative. To make matters worse, online collection method for performance measurement data is still not prevalent among public sector as 64.7 percent (mean, 1.98) say that they use to a little or no extent of such method. Shaman and Kavan (1999) observe that paperbased measurement systems are too slow, cumbersome, labour intensive and unreliable. This might just compound the issue of governance as stated above.

\section{Analysis Methods}

The questions attempt to find out the extent of analysis done on the performance result. The analysis activity is very crucial if the results are going to be used regularly by the executive leadership as well as to help staff monitor progress toward intended program or service results. Results show that majority $(58.8 \%$, mean $=3.55)$ of respondents use qualitative analysis to validate their data through interviews and personal observations. Knowing that there is a lack of technology enabler that is supporting the data collection and recording as found earlier, thus validation tool using interviews and observation is justifiable. With regard to the role of performance data in benchmarking activities, the results reveal that performance data are often being benchmarked with the established targets $(68.6$ percent, mean $=4.06$ ), the national standards or guidelines from federal agencies and/or professional groups (62.7 percent; mean, 3.60), prior periods (41.2 percent; mean, 3.26) and with established thresholds (41.2 percent; mean, 3.18). The overall mean for Analysis is 2.97 which imply that the performance measurement result analysis has only been done in a little extent. These findings are almost similar to Hoque and Adams' (2008) survey that the Australian government uses prior periods (75.0 percent; mean, 3.77) and established targets (60.0 percent; mean, 2.62) as their main benchmarks. The qualitative analysis may not be suitable in most situations as empirical data need to be collected from district, state and departmental levels for purpose of analysis. This finding would reflect that many government agencies do not actually have a robust qualitative analytical tool, welldefined methodologies and IT platform to facilitate them in project measurement/evaluation especially those with multi-billion worth of projects.

\section{Users}

Majority of the respondents reveals that from large to the very large extent, the recipients of the performance measurement reports have been the Implementation Coordination Unit (ICU) (52.9 percent, mean $=3.43)$ and followed by Economic Planning Unit $(E P U)(49.0$ percent, mean $=3.43)$. Other users are the operating managers $(39.2$ percent, mean $=3.10)$ and elected officials $(37.3$ percent, mean $=2.84$ ). This result is understandable because ICU and EPU are two of the four central agencies under the Prime Minister's Office who are involved in planning the country's and policy direction as well as monitoring the physical development throughout the country. Hence, as a large percentage of measurements consist of input, activity/process and outputs, the results would have been useful for EPU and ICU. Surprisingly, Ministry of Finance has had little to no extent of use of the performance report. This might be due to the availability of an automated finance systems like the Electronic Budget Planning and Control System (e-SPKB) and the Standard Accounting System for Government Agencies (SAGA) that link finance divisions of each ministry and agency to the Ministry of Finance and Auditor General's Office, hence reducing the need for additional finance related measures. There were 58.8 percent and 51 percent of the respondents respectively declare that the citizen and media have little use of the performance report. These results however are somewhat different from Hoque and Adam's findings on the Australian government whose 60 percent of respondents replied that the reporting outputs are for the citizens and media. Does this show that the Australian government practices a more open and transparent administration than the Malaysian government? Or does it mean that our citizens are less concern about our right? This study does not have the answer for either question but based on the results, the Malaysian public sector could have been more transparent in its performance reporting especially on issues related to environmental sustainability and social responsibility in order to prevent any environmental mishaps like landslides or cracked highways from happening. In a study conducted by Pollitt (2005) on the European governments, the respondents cited 
that the regularly active external scrutiny seemed to occur only when state agencies are engaged in commercial activities with private sector. Abu Hasan (2009) reports that citizen rarely concerns about the performance measures or disclosures, but they would be more interested in whether services related to them such as repairing roads, collecting garbage, cleaning the roadsides, maintaining public infrastructures and etc are being fulfilled by the public sector organizations. Thus, the findings of this research could suggest that the current performance measures are less useful for the public but more beneficial for the managers and employees of the public sector organizations themselves. It is not uncommon to utilize the measurement indicators for usage of managers and employees in promoting improvement for a sector in the midst of reforming like Malaysia. Internal processes are the direct link to objectives in achieving outcomes, thus, focusing the indicators on the internal processes is vital to ensure processes are of the best set for achieving desired outcomes.

\section{Reporting purpose and Uses}

In terms of reporting purpose, results of this study indicate that the main purposes of reporting have been to a large and very large extent for internal managerial control $(68.6$ percent, mean $=3.92)$ and followed by budget execution $(45.1$ percent, mean $=3.37$ ). This result substantiates the remark by Pollit (2005) that performance measurement and management system is carried out by and for managers. In terms of uses, 60.8 percent of respondents use from large to a very large extent the results of performance measures as a basis for taking actions (mean $=3.76$ ), to manage activity or program (mean $=3.59$ ) and for strategic planning (mean $=3.47$ ), while 45.1 percent are using it to a large and very large extent for measuring program and project performance (mean $=3.10)$. The results also indicate that performance measures are used at a little or no extent to satisfy professional associations $(64.7$ percent, mean $=1.98)$, to follow others $(62.7$ percent, mean $=2.08)$, to measure goals in relation to community impacts $(62.7$ percent, mean $=2.33)$ and to measure environmental goals $(60.8$ percent, mean $=2.27)$.

\section{What are the benefits and important aspects of successful implementation of performance measurement system?}

\section{Benefits}

Performance measurement has promised many benefits since Argyris (1977) claims that performance measurement should contribute to a better understanding of how business works. In this survey, we attempt to identify the extent of benefit of the performance measures that are being used in various managerial activities. Performance measurement system seems to provide benefit largely in improving programmes/service quality (56.9 percent; mean, 3.51), cross agency cooperation /coordination (56.9 percent; mean 3.41), increasing awareness of factors that affect performance results (54.9 percent; mean 3.71), increasing awareness of and focus on result (54.8 percent; mean 3.24) and improving effectiveness of agency programmes (52.9 percent; mean 3.41). The least benefits expected from the performance measurements are to reduce environmental effect (58.8 percent; mean 2.39), changing appropriation level (56.9 percent; mean 2,27), changing the questions the legislators ask government managers or executives (54.9 percent; mean 2.49) and communicating with the public about performance (52.9 percent; mean 2.57). On the question about the important aspects of successful implementation of performance measurement system, results indicate that respondents perceived performance measures help staff monitor progress toward intended program/ service results (mean=3.72), training for management and staff about performance measurement development and selection (mean=3.54) and communication of purpose (mean=3.52) are most important. They also consider that staff participation (mean=3.44), regular use by executive leadership (mean=3.40) and the adequacy of technology for collecting, analyzing and reporting performance measures $($ mean $=3.28$ ) as critical to ensure successful implementation of PMS initiative. These results are quite comparable to those of Hoque and Adam's (2008) study that reveals regular use of performance measures by executive leaderships is the most important, followed by performance measures that help staff monitor progress towards intended program/service results and the adequacy of technology. Consistent with Hoque and Adam's study, results also reveal that additional or changed staffing for collecting, analysing and reporting performance measures is the least important aspect of successful implementation of performance measurement system $($ mean $=2.42)$. 


\section{Shortcomings}

The respondents were also asked to state their opinion on whether their current performance measurement system experiences any shortcomings or weaknesses. These shortcomings are expected to hinder the successful implementation of performance measurement system. The most obvious shortcomings of the performance measurement are that the information is to a large and very large extent, not available on time (70.6 percent; mean, 3,84$)$ and imprecise (68.5 percent; mean, 3.76 ). These results seem consistent with those found in Table 8 regarding the data recording, updating, and collection methods. The overly use of spreadsheet applications and manual data collection indicates that the level of use of IT and information system sophistication (ISS) is still low, hence results in data being not available on time and imprecise. There are 37.3 percent of respondents who say that they have to a large and very large extent too much information and that the information is easy to manipulate. The KPI results information are very crucial for the analysis activities, hence their absence and possible erroneous facts may impede or taint some critical decisions. Marr (2005) observes that even though excel has been primarily used as data collection and analysis tool, most organizations are not happy with the system. PAIB (2008) also concludes that respondents of their survey are much more satisfied with their performance measurement system if it has the capability for capturing, processing and reporting useful information on both financial and non-financial developments. Therefore, it can be concluded that the use of excel and manual data collection would result in major shortcomings as reported above.

\section{CONCLUSION}

The results of the study provide insights into the design of performance measurement system and would have drawn attention to its implementation and usage in the public sector. This study attempts to provide exploratory empirical evidence on how the Malaysian public sectors design their performance measurement system by specifically looking into two aspects: strategic alignment and balanced characteristics. This study found that the public sectors have been to a moderate extent designing their performance measurement system to align to the organisational strategy. Still, the KPIs are found to be less dynamic to reflect the changes in strategy. In examining the balanced nature of performance measurement, this study reveals that there is an overall lack of balanced indicators except for indicators on financial and non-financial such as input, activity and output indicators. Other indicators are not extensively being used such as outcomes, sustainability, innovation, environmental and social responsibility indicators. As the top echelons of the civil servants are calling attention to outcomes-based evaluation of performance, this survey has established to some extent that they might not be quite ready for the push just yet. A successful adoption of performance measurement system is not just about giving the right training nor having the technology to support it; it is about holistic change which involves the people's readiness and their willingness to embrace and institutionalise a transparent and outcome oriented measurement goals and is accountable to it. The study indicates that there is a need for public sector to take into more serious consideration of the outcomes as well as socially and environmentally related measures and link all measurements up in a causal relationship manner.

The overall findings are nevertheless, subject to several limitations. As the questionnaire demands responses from senior executives in order to elicit the prevailing practice of performance measurement in public sector, this study is not able to claim with full certainty that the responses have been made by the senior executives per se. Perhaps due to higher and more critical work obligation, the task might have been delegated to a more junior officer. Other limitation includes the use of survey to capture perceived subjectivity of an issue. Use of survey will not likely be able to dig deeper into a subject matter and solicit better insights from the respondents. Perhaps, a case-study with face-to-face interviews with a number of senior civil servants at various central, federal and state level agencies coupled with a time-series performance data would reveal a much more color to the study. Given the possible impact of the performance measurement results on the management and individual's reputation, it may also be deemed as sensitive to question the strategy. It may even be construed as questioning the management's capability because the senior management has been actively involved in determining the strategy and KPIs. In addition, since the cultural dimension of management style within the Malaysian Public Sector who are coincidently, predominantly Malay, who according to Abdullah (1996) have the main work values of "preserving face", hence, it is possible that the act of 
questioning other people's performance would have been deemed as obtrusive which would have been avoided at all cost and blame the data integrity for the poor performance. The lack of questioning and analysis may be due to the inside-out practice of choosing performance measurement. This could potentially be detrimental to the implementation initiative as the integrity of the whole system may be questionable. As a result, everyone would be starting to lose faith and interest in the PMS and may decide to abandon the whole initiative, which in the end, would put the whole government machinery at risk. 


\section{REFERENCES}

Abdullah, R. T. (2008). Bukan Melayu Dipinggirkan? Utusan Online 25/11/2008. Available from: http://www.utusan.com.my/utusan/info.asp? $\mathrm{y}=2008 \& \mathrm{dt}=1125 \& \mathrm{pub}=$ utusan_malaysia\&sec=Rencana \&pg=re_02.htm\&arc=hive, last accessed 30 June, 2010

Abu Hasan, H. (2009) The Impact of External Audit and Use of Resources Assessment on Local Authorities: A Study of Yorkshire and The Humber Region of England, PhD Thesis (Unpublished), University of Sheffield, UK

Ahmad, F. (2007). Cina, India tak minat. The Malaysian Bar. 24/12/2007, http://www.malaysianbar.org.my/berita/komen_undang_undang/cina_india_tak_minat.html, last accessed 30 June, 2010

Anand, M., Sahay, B. S., \& Saha, S. (2005, Apr \& Jun). Balanced Score Card in Indian Companies. VIkalpa, pp. 11-25

Atkinson, A. A., Waterhouse, J. H. and Wells, R. B. (1997). "A stakeholder approach to strategic performance measurement." Sloan Management Review Spring: 25-37.

Bertok, J., Hall, J., Kraan, D.-J., Malinska, J., Manning, N., \& Matthews, E. (2006). Issues in outcome measurement for 'Government at a glance'. OECD project on Management in Government Technical Paper 3. Paris: OECD.

Carter, N. (1991) "Learning to measure performance: the use of indicators in organizations", Public Administration, Vol. 69(1), pp. 85-101

Chan, Y. L. (2002). "The benefits of balance: the balanced scorecard is not yet embraced by Canadian municipal governments, but it could be exactly what they need", CMA Management, December.

Classe, A. (1999). "Performance anxiety”. Accountancy, Vol. 123 (1267), pp. 56-58

Dixon, John et al. (1996). "The commercialization of the Australian public service and the accountability of government: A question of boundaries", The International Journal of Public Sector Management, Bradford, Vol. 9(5/6), p.23

Dixon, John et al. (1998). "Managerialism - something old, something borrowed, little new Economic prescription versus effective organisational change in public agencies", The International Journal of Public Sector Management, Vol.11(2/3), p.164

Dixit, A. (2002) 'Incentives and Organizations in the Public Sector: An Interpretive Review', Journal of Human Resources, Vol. 37 (4), pp. 696-727

Eccles, R. G. (1991) The Performance Measurement Manifesto. Harvard Business Review, 69(1), pp. 131-137.

Flynn, N. (1993) Public Sector Management, Biddles Ltd, UK

Herzlinger, E. R. (2000), Businessline, Chennai: Jul. 13, p.1

Ho, S. K. and Chan, Y. L. (2002), "Performance measurement and the implementation of balanced scorecards in municipal governments", The Journal of Government Financial Management, Alexandria: Winter, Vol. 51(4), p. 8.

Hoque, Z. and Adams, C. (2008). Measuring public sector performance. A study of government departments in Australia. Publication pending in 2009. Available from:

http://www.cpaaustralia.com.au/cps/rde/xbcr/SID-3F57FECB-

C5784B9E/cpa/measuring_public_sector_performance_200808.PDF, last accessed 30 June, 2010

Henri, J. F. (2004). Performance Measurement And Organisational Effectiveness: Bridging The Gap. Managerial Finance Vol. 30(6), pp. 93-123.

Jusoh, R., Ibrahim, D. N. and Zainuddin, Y (2006). Assessing the alignment between business strategy and use of multiple performance measures using interaction approach. The Business Review.

Cambridge, Vol 5 (1), pp 51-60.

Jusoh, R., Ibrahim, D. N. and Zainuddin, Y. (2008). "The performance consequence of multiple performance measures usage: Evidence from the Malaysian manufacturers. International Journal of Productivity and Performance Management, Vol. 57(2), pp. 119-136 
Jusoh, R. and Parnell, J. (2008). Competitive strategy and performance measurement in the Malaysian context: An exploratory study, Management Decision, Vol. 46(1), pp. 5-31

Ittner, C. D. and D. F. Larcker (1998a). "Are nonfinancial measures leading indicators of financial performance? An analysis of customer satisfaction." Journal of Accounting Research, Vol. 36(Supplement), pp. 1-35.

Ittner, C. D. and D. F. Larcker (2001). "Assessing empirical research in managerial accounting: a value-based management perspective." Journal of Accounting and Economics, Vol, 32, pp. 349-410

Kald, M. and Nilsson, F. (1999). Performance measurement at Nordic companies. European Management Journal, Vol. 18(1), pp. 113-127

Kaplan, R. S. and D. P. Norton (1992). "The balanced scorecard - Measures that drive performance." Harvard Business Review, January-February, pp. 71-79

Kaplan, R. and D. Norton. (1996). The Balanced Scorecard: Translating Strategy into Action. Harvard Business School Press, Boston, MA.

Mackay, Keith (2007). How to build M\&E systems to support better government, The International Bank for Reconstruction and Development / The World Bank. Available from:

http://www.worldbank.org/ieg , last accessed 30 June, 2010

Marr, B. (2005). Business performance measurement: an overview of the current state of use in the USA. Measuring Business Excellence. 2005. Vol. 9, No. 3. pp 56-62

Nanni, A. J., R. Dixon and T. E. Vollmann (1992). "Integrated performance measurement: management accounting to support the new manufacturing realities." Journal of Management Accounting Research, Vol. 4 (Fall), pp. 1-19

Niven, P.R. (2002). Balanced Scorecard Step-By-Step. John Wiley \& Sons, Inc., New York

Niven, P. R. (2003). Balanced Scorecard Step-By-Step for Government and Non-profit Agencies, $2^{\text {nd }}$ Edition, John Wiley \& Sons, New York

OECD (1993) Public Management Developments: Survey 1993, OECD, Paris

Osbourne, D. and Gaebler, T. (1992) Reinventing Government, Lexington, MA, Addison-Wesley

Osborne, D. and Gaebler, T. (1993) Reinventing Government: How the Entrepreneurial Spirit is Transforming the Public Sector. New York: Penguin

Othman, Rozhan et al. (2004) A Case Study Of Balanced Scorecard Implementation: The Hidden Problems. Available from:

http://faculty.kfupm.edu.sa/coe/sadiq/proceedings/SCAC2004/40.ASC017.EN.Othman.A percent20Case percent20Study percent20of percent20Balance percent20Scorecard percent20Im percent20_1_.pdf, last accessed 30 June, 2010

Pollit, Christopher (2005). Performance management in practice: A comparative study of executive agencies. Journal of Public Administration Research and Theory. Vol. 16, pp. 25-44

Prime Minister's Office (2009). “Senarai anggota pentadbiran kerajaan persekutuan”. Available from: www.pmo.gov.my, last accessed 30 June, 2010

Quade, E. S. (1980). Pitfalls in formulation and modelling. G. Majone, \& E. S. Quade Pitfalls of analysis. Chichester: John Wiley \& Sons, pp. 23-43

Randor, Zoe and Lovell, Bill (2003), "Defining, Justifying and Implementing the Balanced Scorecard in the National Health Service", International Journal of Medical Marketing, London, June, Vol. 3, 1ss. 3, p.174.

Rigby, D. (2003). Management tools survey: Usage as companies strive to make headway in tough times. Strategy \& Leadership, 31 (5), pp. 4-11

Sharman, P. and Kavan, C.B. (1999). Software is not the solution: software selection's effect on implementing the balanced scorecard. Journal of Strategic Performance Management.

February/March, pp. 7-15

Spathis, Charalambos and Constantinides, Sylvia (2003). The usefulness of ERP systems for effective management, Journal of Industrial Management and Data System, Vol 103(9), pp 677-685 
Journal of Global Strategic Management | V. 6 | N. 1 | 2012-June | isma.info | 42-56 | DOI: 10.20460/JGSM.2012615785

Steven Van De Walle. 2007. International Comparisons Of Public Sector Performance: How To Move Ahead? Presented At IRSPM XI, Potsdam, 2-4 April 2007

Walker, D.M. (2000), Managing Human Capital in the 21st Century, GAO/T-GGD-00-77, United States General Accounting Office, Washington, DC 